\title{
JUDĖJIMO NEGALIĄ TURINČIŲ ASMENŲ PSICHOLOGINIŲ RESURSŲ REIKŠMĖ PRISITAIKYMUI PRIE NEGALIOS
}

\author{
Laura Alčiauskaitė, Liuda Šinkariova \\ Vytauto Didžiojo universitetas
}

Raktažodžiai: psichologiniai resursai, prisitaikymas prie negalios, judejjimo negalia.

\begin{abstract}
Santrauka
Pastaraisiais metais didèja susidomèjimas judèjimo negalią turinčių asmenų psichologiniais resursais, tačiau neretai šie tyrimai apsiriboja pavienio konstrukto analize. Kiekvienas tyrimas išskiria vis naujus neiggaliajam svarbius resursus, o tokia reiškinių gausa ne palengvina, o apsunkina vidinių resursų supratimą, suvokimą ir matavimą. Tad šio darbo tikslas - išskirti psichologinius resursus, reikšmingus judejjimo negalią turinčių asmenų prisitaikymui prie negalios.

Šio tyrimo metu atrinkti 45 moksliniai darbai, kuriuose buvo analizuojamos judejjimo negalią turinčių asmenų psichologinių resursų ir prisitaikymo prie negalios aspektų tarpusavio sąsajos. Dažniausiai nagrinèjami psichologiniai resursai - suvokiama socialinè parama, saviveiksmingumas, streso ịveikos strategijos ir savivertè, iš kurių visi, išskyrus savivertę, siejasi su fiziniais, psichologiniais bei socialiniais prisitaikymo prie negalios aspektais.
\end{abstract}

\section{Ivadas}

Prisitaikymas prie negalios yra apibrèžiamas kaip negalią turinčio asmens reakcija i jo negalios sąlygotus funkcinius, psichologinius ir socialinius pokyčius [1]. Pastebèta, jog netgi asmenys, turintys tokią pačią ar panašią negalią, gali labai skirtingai vertinti savo neigalumą: vieni jų teigia, kad nekenčia savo negalios ir jaučiasi niekam tikę, kiti pripažįsta turimus sveikatos sunkumus, tačiau yra įsitikinę, jog tai nẻra kliūtis gyventi prasmingą ir pilnavertị gyvenimą. Visa tai ir rodo, kiek asmuo yra prisitaikęs gyventi su savo negalia. Apskritai, geras asmens prisitaikymas prie negalios turètų būti kiekvienos psichosocialinès reabilitacijos siekiamybè, nes tik su savo negalia išmokęs gyventi žmogus nesureikšmina savo fizinių trūkumų ir suvokia, kad jis turi kitų stiprybių bei gebejjimų, jaučiasi išdidus, patenkintas ir laimingas [2].
Prisitaikymo procesui labai svarbūs fiziniai ir psichologiniai veiksniai, tačiau atliktuose moksliniuose tyrimuose didesnis dèmesys skiriamas prisitaikymą apsunkinantiems veiksniams ir probleminėms negalios sritims, tokioms kaip sumažèjęs savarankiškumas, diskriminacija, socialinè stigma, depresija, padidejjusi priklausomybių ar savižudybės rizika, patiriami psichosocialiniai sunkumai [3]. Tuo tarpu neigaliojo turimiems psichologiniams resursams ir galimybèms juos stiprinti demesio skiriama gerokai mažiau.

Psichologiniai resursai suprantami kaip vidiniai, sveikatą apsaugantys ar gerinantys veiksniai, kurių paskirtis - padèti asmeniui ịveikti kylančius sunkumus ar stresines situacijas. Psichologiniais resursais gali būti asmens turimi gebejjimai ar talentai, igūdžiai, žinios, asmenybès stiprybès ar elgesys [4]. Jie yra svarbūs bet kuriam asmeniui, o ypač tais atvejais, kai tenka susidurti su įvairiais sunkumais ar iššūkiais. Stiprūs vidiniai resursai ne tik didina žmogaus atsparumą kasdieniams stresogeniniams įvykiams, bet ir padeda išvengti ilgalaikio distreso, kuris, savo ruožtu, gali sukelti įvairias somatines ir psichikos ligas [5]. Ypač tai svarbu kalbant apie neiggalius asmenis, kurie dažniau nei sveikieji susiduria su ivvairiais sunkumais ir patiria daugiau distreso. Pati negalia jau ir taip yra nemenkas iššūkis ją turinčiam asmeniui, tad vidinių resursų stiprinimas ne tik padètų ịveikti kylantị distresą, pagerintų jų sveikatą bei savijautą, bet ir padètų asmeniui labiau prisitaikyti prie negalios. Pastaraisiais metais mokslinèje literatūroje didèja susidoméjimas judèjimo negalią turinčių asmenų psichologiniais resursais, tačiau neretai šie tyrimai apsiriboja pavienio konstrukto analize. Kiekvienas tyrimas išskiria vis naujus neigaliajam svarbius resursus, o tokia reiškinių gausa ne palengvina, o apsunkina vidinių resursų supratimą, suvokimą ir matavimą [6]. Tad manome, jog labai svarbu išskirti reikšmingiausius iš jų, kurie yra labiausiai susiję su asmens negalios prièmimu. Toks stipriujų asmenybės pusių išryškinimas ne tik leistų geriau suprasti prisitaikymo prie negalios procesą, bet ir suteiktų gaires psichosocialinès reabilitacijos programoms, taip siekiant padèti negalią turintiems asmenims ịveikti negalios sąlygotus sunkumus. 
Siekiant minèto tikslo, išskirti šie tyrimo uždaviniai:

1. Atrinkti elektroninèse duomenų bazèse mokslines publikacijas, nagrinèjančius judejjimo negalią turinčių asmenų psichologinių resursų ir prisitaikymo prie negalios sąsajas. 2. Išskirti psichologinius resursus, labiausiai reikšmingus asmens prisitaikymui prie negalios.

Tyrimo tikslas: išskirti psichologinius resursus, reikšmingus judejjimo negalią turinčių asmenų prisitaikymui prie negalios.

\section{Tyrimo metodas}

Šiame darbe buvo analizuoti tik tie tyrimai, kurie: 1) atlikti su judejjimo negalią turinčiais asmenimis; 2) tiriamieji yra pilnamečiai; 3) tyrime analizuojami psichologiniai resursai ir prisitaikymas prie negalios; 4) tyrimo duomenys buvo kiekybiniai; 5) tyrime nebuvo taikyta psichologine intervencija. Analizuoti tik laisvai elektroninèse duomenų bazèse prieinami visateksčiai recenzuoti straipsniai. Vykdant paiešką nebuvo taikomi publikavimo metu apribojimai.

Ruošiant šị straipsnị, apžvelgtos šios bibliografinès duomenų bazės Medline, PsychArticles, HealthSource: Nursing/ AcademicEdition, Academic Search Complete, SpringerLink ir ScienceDirect. Straipsnių paieška buvo atlikta pagal raktažodžių matricą, ịvestą ị duomenų bazių paieškos lauką.
Naudota raktažodžių matrica: adjustment or acceptance and disability and psychological resource*. Buvo pasinaudota duomenų bazių išplèstine paieška, pažymint, kad ị paiešką būtų įtraukiami pateiktų raktažodžių sinonimai. Paieškos rezultatai buvo pateikti trimis kalbomis: anglų, vokiečių ir rusų.

Bibliografinès duomenų bazès pagal nurodytus paieškos kriterijus atrinko 3270 mokslines publikacijas. Publikacijų paieškos ir atrankos eiga pateikta 1 paveiksle.

Po pirminès straipsnių peržiūros buvo atmestos 3056 itraukimo kriterijų neatitinkančios publikacijos, po antrinès - 169 publikacijos: neitraukti tie tyrimai, kuriuose tiriamieji neturejjo negalios ar jų negalia buvo ne judejimo; tyrimas atliktas su nepilnamečiais; nebuvo analizuoti psichosocialiniai resursai ar/ir asmens prisitaikymas prie negalios; buvo atliktas intervencinis ar kokybinis tyrimas; tyrimas buvo ne iš psichologijos, bet kitų mokslų srities (pvz., teisès, architektūros, ekonomikos).

I analizę taip pat nebuvo ịtraukti ir teoriniai (kiekybinių duomenų neturintys) straipsniai, metaanalizès ar sisteminès analizės, knygų skyriai, mokslinių konferencijų santraukos ar moksliniai komentarai. Neįtraukti ir trys straipsniai, parašyti ispanų kalba, nes nebuvo galima atlikti kokybiškos šių straipsnių analizès. Dviejų tyrimų dalyviai turejo ne tik judèjimo, bet ir intelekto negalią - šių tyrimų rezultatai taip pat nebuvo analizuojami.

Likę 214 straipsnių buvo

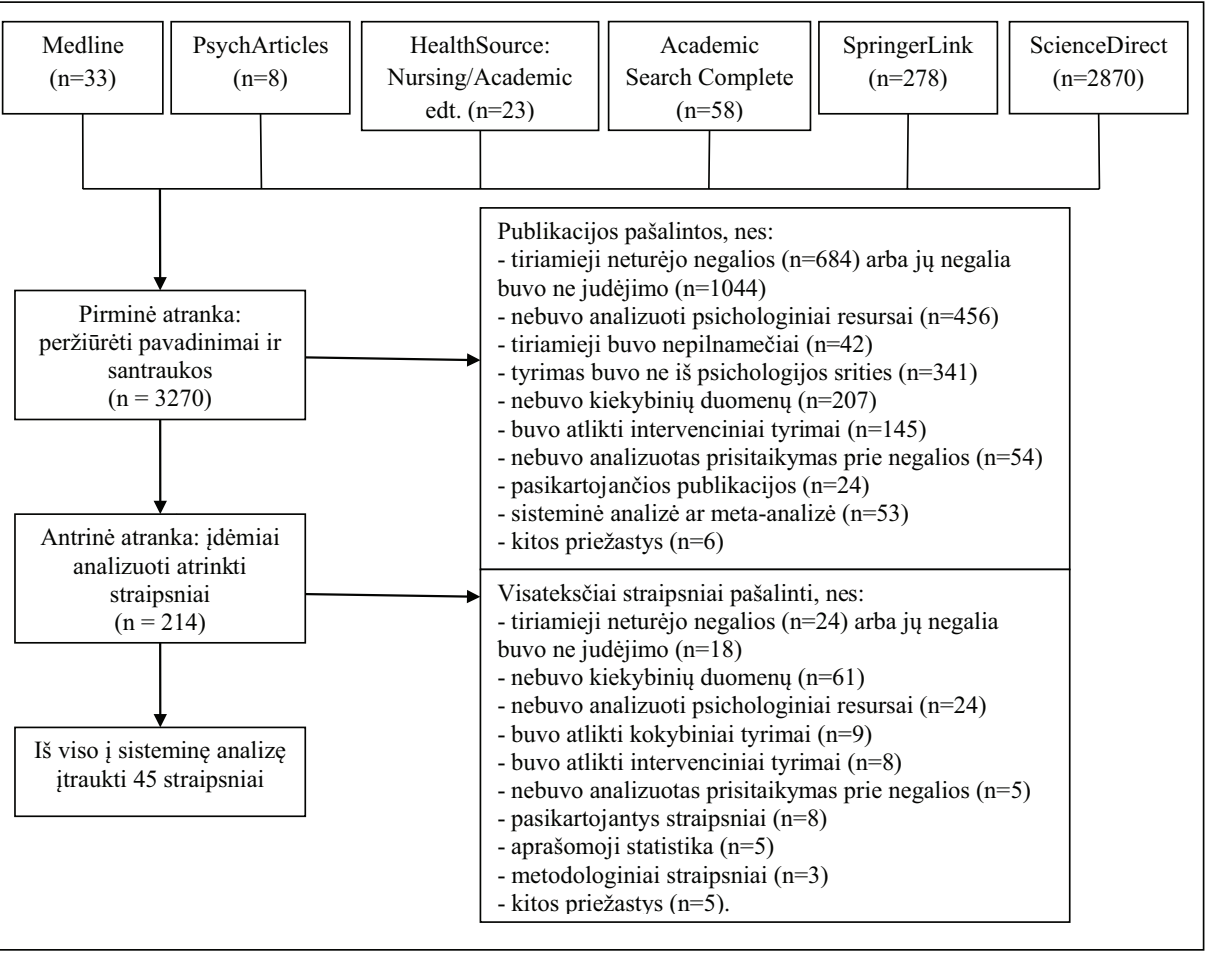

1 pav. Publikacijų atrankos sisteminei literatūros apžvalgai eiga ìdèmiai išanalizuoti antrinès peržiūros metu, remiantis minetais atrankos kriterijais.

Galiausiai išsikeltus kriterijus atitiko ir ị analizę įtraukti 45 moksliniai tyrimai.

\section{Rezultatai}

Siekiant aukštesnès duomenų kokybės, buvo atrinkti tik visateksčiai straipsniai, publikuoti recenzuojamuose moksliniuose leidiniuose, kuriuose keliami ganètinai aukšti tyrimo dizaino reikalavimai.

Šiame darbe nagrinèjami rezultatai, gauti naudojant kiekybinius tyrimo metodus paprastą anketavimą $(\mathrm{n}=25)$, apklausą paštu $(\mathrm{n}=7)$ ar internetu $(n=2)$. Kai tiriamujų negalia būdavo sunki, apklausa buvo atliekama tyrejjui klau- 
siant ir žymint tiriamojo atsakymus $(\mathrm{n}=6)$. Keturiuose tyrimuose taikytas mišrus apklausos būdas (paštu ar telefonu), o S. Schneider ir kt. [7] tiriamieji pildè ne tik anketą, bet ir patiriamo skausmo dienoraštị.

Buvo analizuoti tik tie tyrimai, kuriuose tiriamieji turèjo judejimo negalią, nors pačios negalios priežastys buvo ivvairios: daugiausia tyrimų atlikta su asmenimis, sergančiais lètinemis sąnarių ligomis - reumatiniu artritu, osteoartritu ar kuria kita artrito forma $(\mathrm{n}=27)$ bei patyrusių stuburo smegenu pažeidimą $(n=6)$. Kai kuriuose tyrimuose $(n=4)$ tiriamujų grupe buvo mišri ir negalios priežastys buvo skirtingos.

Lyties atžvilgiu tiriamujų grupès nebuvo homogeniškos: dažniausiai tiriamųjų daugumą sudare moterys $(n=32)$, kiek rečiau $(\mathrm{n}=10)$ - vyrų. Trijuose tyrimuose apklausiamos buvo tik moterys.

Visi tyrimuose dalyvavę asmenys buvo pilnamečiai, savanoriškai sutikę dalyvauti tyrime ir neturintys jokių kognityvinių funkcijų ar psichiatrinių sutrikimų.

Pirmiausia, šios analizès metu buvo išskirti dažniausiai tyrimuose nagrinèti judejjimo negalią turinčiu asmenų psichologiniai resursai (1 lentelè). Joje nepateikti psichologiniai resursai, kurie buvo nagrinèti tik po vieną kartą. Matyti, jog iš vidinių resursų dažniausiai tyrimuose analizuojami subjektyviai suvokiama socialinè parama, saviveiksmingumas, streso įveikos strategijos bei saviverte - kiekvienas iš jų analizuotas ne mažiau nei šešis kartus. Kiek rečiau sutinkami vidinès darnos jausmas, viltis bei gyvenimo prasmès suvokimas. Kiti resursai ị sisteminę analizę įtrauktuose straipsniuose buvo tyrinejjami po du kartus ar rečiau.

Analizuojant straipsnius taip pat paaiškejjo, kad skirtinguose tyrimuose buvo vertinami vis kiti prisitaikymo prie negalios aspektai, kuriuos galima suskirstyti i tris grupes - 1) fizinius, 2) psichologinius ir 3) socialinius prisitaikymo prie negalios aspektus.

Po to buvo analizuota, kaip jau minèti psichologiniai resursai - suvokiama socialine parama, saviveiksmingumas, streso įveikos strategijos ir saviverté - sąveikauja su fiziniu, psichologiniu bei socialiniu prisitaikymo prie negalios aspektais ir kokios jų sąsajos buvo nustatytos į sisteminę analizę įtrauktuose tyrimuose.

Paaiškèjo, kad suvokiama socialinè parama, saviveiksmingumas ir streso ịveikos strategijos reikšmin-

2 pav. Psichologinių resursų sąsajos su prisitaikymo prie negalios aspektais

1 lentèlė. Dažniausiai analizuoti psichologiniai resursai

\begin{tabular}{|l|c|}
\hline Psichologinis resursas & N \\
\hline Subjektyviai suvokiama socialinė parama [8-21] & 14 \\
\hline Saviveiksmingumas [7-8,14,22-30] & 12 \\
\hline Streso ivveikos strategijos [9,17-18,23,31-35] & 10 \\
\hline Saviverte $[8,14,18,25,36-37]$ & 6 \\
\hline Vidinės darnos jausmas [22,31,38-39] & 4 \\
\hline Viltis [24,31,40] & 3 \\
\hline Bendrosios gyvenimo prasmės suvokimas [23,29,41] & 3 \\
\hline Asmenybės bruožai [15,38] & 2 \\
\hline Optimizmas [24, 40] & 2 \\
\hline $\begin{array}{l}\text { Asmenybės atsparumas [42-43] } \\
\text { Ramirez-Maestre, Esteve, 2014; Silvermann ir kt., } \\
\text { 2015) }\end{array}$ & 2 \\
\hline Gebejimas siekti tikslo [29,43] & 2 \\
\hline Lankstumas siekiant tikslo [29,43] & 2 \\
\hline
\end{tabular}

gai sąveikauja su visais trimis prisitaikymo prie negalios aspektais. Vienintelis psichologinis resursas - saviverte - siejasi tik su psichologiniu asmens prisitaikymu prie negalios, tuo tarpu reikšmingų sąsajų su fiziniu ir socialiniu aspektais nagrinètuose tyrimuose nerasta. Šių reiškinių sąsajas galima pavaizduoti schematiškai (2 pav.).

\section{Diskusija}

Pagrindinis šio tyrimo tikslas buvo išskirti psichologinius resursus, reikšmingus judejjimo negalią turinčių asmenu prisitaikymui prie negalios. Tikslui pasiekti buvo atrinkti 45 moksliniai straipsniai, kuriuose atliktu tyrimų metu buvo vertinamos vertinamos psichologinių resursų ir prisitaikymo prie judėjimo negalios aspektų tarpusavio sąsajos.

Nors stebima didžiulè mokslininkus dominančiu vidiniu resursų įvairovė, išanalizavus atrinktus straipsnius, paaiškẻjo, 
jog labiausiai tyrinèti iš jų - subjektyviai suvokiama socialinè parama, saviveiksmingumas, streso įveikos strategijos bei saviverte.

Gauti rezultatai nenustebino - minèti resursai išties yra itin reikšmingi bet kurio asmens sèkmingam funkcionavimui, gerai sveikatai bei savijautai, o neiggalaus asmens atžvilgiu - tampa esminiu faktoriumi, sąlygojančiu, kaip neigalusis sugeba įveikti jo gyvenime kylančius iššūkius. Aukštas asmens saviveiksmingumas ir saviverté, didele artimujų ar draugų teikiama parama bei efektyviai naudojamos ịveikos strategijos padeda išvengti distreso ir neigiamų jo pasèkmių, skatina asmenį aktyviau siekti savo tikslų, didina pasitikèjimą savimi, skatina aktyvesnį dalyvavimą visuomeneje, sumažina depresijos, nerimo sutrikimų ir kitų lètinių ligų riziką [45]. Tad ugdant šias žmogaus turimas stiprybes galima ženkliai pagerinti jo savijautą, sveikatą ir bendrą psichosocialinị funkcionavimą, nepaisant negalios keliamų apribojimų.

Kita vertus, bandant išskirti reikšmingiausius resursus, teko susidurti su keletu sunkumų, kuriuos galima priskirti tyrimo ribotumams. Vienas iš jų yra tas, kad tiriamųu judèjimo negalia buvo skirtingo pobūdžio. Kaip minèta, dauguma tiriamujų buvo patyrę stuburo smegenų pažeidimus arba sergantys lètinèmis sąnarių ligomis, tačiau išties judejimo negalios priežasčių gali būti daug ir ịvairių - pvz., cerebrinis paralyžius, galūnių amputacijos, stuburo pažeidimai, osteoporozė ir kt. Nors šiuo tyrimu siekta išsiaiškinti, kokie resursai yra reikšmingi asmenims, nepriklausomai nuo jų negalios pobūdžio, siekiant aukštesnio tyrimo išorinio validumo geriausia sisteminę analizę atlikti su kuo labiau homogeniška grupe, kad remiantis gautais rezultatais būtų galima daryti išvadas apie visą sergančiujų populiaciją. Tačiau šị tikslą igyvendinti yra sudètinga dẻl didelès tiriamujų įvairovès.

Kitas šios sisteminès apžvalgos ribotumas - ją atliekant nebuvo atsižvelgta ị tyrimuose naudotą vertinimo metodiką. Kiekvieną psichologinị reiškinį galima išmatuoti naudojant skirtingą klausimyną ar atsižvelgiant ị skirtingus aspektus pavyzdžiui, galima matuoti subjektyviai suvokiamą paramą, gaunamą iš draugų, šeimos narių, medicinos darbuotojų ar bendrai. Saviveiksmingumas taip pat gali būti ịvairių tipų, priklausomai nuo srities, kurioje asmuo jaučiasi pajėgus (ar atvirkščiai - nepajègus) pasiekti norimų tikslų. Nors daugelyje ị sisteminę analizę ịtrauktų tyrimų buvo vertinamas bendras saviveiksmingumas, kai kuriais atvejais tyrejjus domina specifinis, pvz, skausmo įveikimo ar nuotaikos reguliavimo saviveiksmingumas [22,25].

Skirtingai buvo matuojamos ir streso ịveikos strategijos - nors bene dažniausiai tyrejjų pasirenkamas klausimynas COPE ar sutrumpinta jo versija [23,31], tačiau naudojami ir kiti metodai, išskiriantys kitas įveikos strategijas, iš kurių kai kurios yra reikšmingos prisitaikymui prie negalios. Tokia gausa skirtingai matuojamų reiškinių sisteminèje analizèje inneša sumaišties ir apsunkina rezultatų supratimą bei pateikimą. Tačiau vélgi - sudètinga rasti tyrimų, naudojančių identiškus klausimynus ir siekiančių ịvertinti tuos pačius reiškinius.

Nepaisant to, šis tyrimas buvo vienas iš pirmujų bandymų išskirti tuos psichologinius resursus, kurių reikšmė prisitaikant prie negalios yra didžiausia. Kita vertus, ar tai, kad šie resursai yra dažniausiai nagrinèjami moksliniuose tyrimuose, reiškia, kad jie neịgaliam asmeniui yra svarbiausi? Gal svarbesni yra būtent tie resursai, kurie sutinkami rečiau? Gali būti ir taip, kad kiekvienam asmeniui resursų reikšmè yra nevienoda, tačiau tam nustatyti reikia atlikti daugiau ir platesnio masto tyrimų.

Pats prisitaikymas yra sudetingas konstruktas, sudarytas iš fizinio, psichologinio bei socialinio prisitaikymo prie negalios aspektų, ką ir patvirtino atlikta literatūros apžvalga. Šie trys aspektai yra glaudžiai tarpusavyje susiję, ir vienodai svarbūs asmeniui sėkmingai prisitaikant prie turimos negalios, tačiau analizuotuose tyrimuose stebima tendencija, jog dažniausiai tyrèjus domina būtent fiziniai prisitaikymo aspektai ir jų sąsajos su psichologiniais resursais. Psichologiniai aspektai analizuotuose tyrimuose taip pat neretai sutinkami, tačiau dažniausi iš jų - būtent negatyvūs reiškiniai, tokie kaip nerimas ir depresiškumas ar patiriami psichosocialiniai sunkumai. Nors pastaruoju metu pozityviosios psichologijos atstovai siūlo atliekant tyrimus orientuotis ị pozityvius su negalia susijusius išgyvenimus ir patirtis, tačiau tokių tyrimų dar nèra gausu. Psichologijoje, neigaliujų reabilitacijos bei integracijos tyrimuose vis dar akcentuojamas fizinis negalios aspektas ir neigiamos jos pasekmès, užuot analizavus neigaliujų turimas vidines stiprybes ir galimybes. Manome, kad itin svarbu ne tik ịvardinti negalios sukeliamas problemas, su kuriomis susiduria neigalieji, bet ir ieškoti veiksnių, padedančių neigaliajam emociškai priimti savo negalią ir kuo efektyviau prisitaikyti gyventi su jos sąlygotais apribojimais. Pozityvus požiūris ị negalią ir negalią turintị asmenị ịgalintų sveikatos priežiūros specialistus ieškoti galimybių ir būdų, kaip sustiprinti neigaliojo turimus vidinius resursus, taip užtikrinant geresnę sveikatą, savijautą ir gyvenimo kokybę.

\section{Išvados}

1. Stebima didelè analizuojamų resursų įvairovè, tačiau dažniausiai sutinkami - suvokiama socialinè parama, saviveiksmingumas, streso įveikos stretegijos ir savivertė.

2. Labiausiai tyrejus domina psichologinių resursų ir fizinio prisitaikymo prie negalios aspektų tarpusavio ryšys, tuo tarpu sąsajoms su psichologiniu ir socialiniu prisitaikymo aspektais skiriama mažiau dèmesio.

\section{Literatūra}




\section{2}

1. Falvo D. Medical and psychosocial aspects of chronic illness and disability. Jones Bartlett Publishers, 2013.

2. Martz E, Livneh H. Psychosocial adaptation to disability within the context of positive psychology: findings from the literature. Journal of Occupational Rehabilitation 2016; 26:4-12.

3. Post MWM, Van Leeuwen CMC. Psychosocial issues in spinal cord injury: a review. Spinal Cord 2012; 50(5):382-389.

4. Hobfoll SE. Social and psychological resources and adaptation. Review of General Psychology 2002;6(4):307.

5. Folkman S. Stress: appraisal and coping. In Encyclopedia of behavioral medicine. Springer New York, 2013;1913-1915.

6. Peter C, Müller R, Cieza A, Geyh S. Psychological resources in spinal cord injury: a systematic literature review. Spinal Cord 2012;50(3):188-201.

7. Schneider S, Junghaenel DU, Keefe FJ, Schwartz JE, Stone AA, Broderick JE. Individual differences in the day to day variability of pain, fatigue, and well being in patients with rheumatic disease: associations with psychological variables. Pain, 2012;153:813-822.

8. Abraido Lanza AF. Social support and psychological adjustment among Latinas with arthritis: a test of a theoretical model. Annals of Behavioral Medicine 2004;27:162-171.

9. Curtis R, Groarke A, Coughlan R, Gsel A. Psychological stress as a predictor of psychological adjustment and health status in patients with rheumatoid arthritis. Patient education and counseling 2005;59(2):192-198.

10. López Martínez AE., Esteve Zarazaga R, Ramírez Maestre C. Perceived social support and coping responses are independent variables explaining pain adjustment among chronic pain patients. The Journal of Pain 2008;9(4):373-379.

11. Evers AW, Kraaimaat FW, Geenen R, Jacobs JW, Bijlsma JW. Pain coping and social support as predictors of long term functional disability and pain in early rheumatoid arthritis. Behaviour research and therapy, 2003;41:1295-1310.

12. Raichle KA, Hanley M, Jensen MP, Cardenas DD. Cognitions, coping, and social environment predict adjustment to pain in spinal cord injury. The Journal of Pain 2007;8:718-729.

13. Harris ML, Loxton D, Sibbritt DW, Byles JE. The relative importance of psychosocial factors in arthritis: Findings from 10,509 Australian women. Journal of Psychosomatic Research. 2012;73:251-256.

14. Kendall E, Terry D. Predicting emotional well being following traumatic brain injury: a test of mediated and moderated models. Social Science \& Medicine 2009;69:947-954.

15. Evers AW, Kraaimaat FW, Geenen R, Bijlsma JW. Psychosocial predictors of functional change in recently diagnosed rheumatoid arthritis patients. Behaviour research and therapy, 1998;36:179-193.

16. Krokavcova M, van Dijk JP, Nagyova I, Rosenberger J, Gavelova M, Middel B. et al. Social support as a predictor of perceived health status in patients with multiple sclerosis. Patient Education and Counseling 2008;73:159-165.
17. McCabe MP, McKern S, McDonald E. Coping and psychological adjustment among people with multiple sclerosis. Journal of Psychosomatic Research 2004;56:355-361.

18. Kwakkenbos L, van Lankveld WG, Vonk MC, Becker ES, van den Hoogen FH, van den Ende CH. Disease related and psychosocial factors associated with depressive symptoms in patients with systemic sclerosis, including fear of progression and appearance self esteem. Journal of Psychosomatic Research 2012;72:199-204.

19. Romano JM, Jensen MP, Turner JA. The chronic pain coping inventory 42: reliability and validity. Pain, 2003;104:65-73.

20. Garcia Campayo J, Pascual A, Alda M, Ramirez MTG. Coping with fibromialgia: usefulness of the chronic pain coping inventory 42. Pain, 2007;132:68-76.

21. Dysvik E, Lindstrøm TC, Eikeland OJ, Natvig GK. Health related quality of life and pain beliefs among people suffering from chronic pain. Pain Management Nursing 2004;5:66-74.

22. Sinikallio SH, Helminen EE, Valjakka AL, Väisänen Rouvali RH, Arokoski JP. Multiple psychological factors are associated with poorer functioning in a sample of community dwelling knee osteoarthritis patients. Journal of Clinical Rheumatology 2014;20:261-267.

23. Peter C, Müller R, Post MW, van Leeuwen C, Werner CS, Geyh S. Depression in spinal cord injury: assessing the role of psychological resources. Rehabilitation Psychology 2015;60:67-80.

24. Skolasky RL, Mackenzie EJ, Riley LH, Wegener ST. Psychometric properties of the patient activation measure among individuals presenting for elective lumbar spine surgery. Quality of Life Research 2009; 18:1357-1366.

25. Barnwell AM, Kavanagh DJ. Prediction of psychological adjustment to multiple sclerosis. Social Science \& Medicine 1997;45:411-418.

26. Sardá J, Nicholas MK, Asghari A, Pimenta CA. The contribution of self-efficacy and depression to disability and work status in chronic pain patients: A comparison between Australian and Brazilian samples. European Journal of Pain 2009;13:189-195.

27. Pells JJ, Shelby RA, Keefe FJ, Dixon KE, Blumenthal JA, LaCaille L. et al. Arthritis self efficacy and self efficacy for resisting eating: relationships to pain, disability, and eating behavior in overweight and obese individuals with osteoarthritic knee pain. Pain, 2008;136:340-347.

28. Schmitz U, Saile H, Nilges P. Coping with chronic pain: flexible goal adjustment as an interactive buffer against pain related distress. Pain, 1996;67;41-51.

29. Arends RY, Bode C, Taal E, Van de Laar MA. The role of goal management for successful adaptation to arthritis. Patient Education and Counseling 2013;93:130-138.

30. van Leeuwen CM, Post MW, Westers P, van der Woude LH, de Groot S, Sluis T. et al. Relationships between activities, participation, personal factors, mental health, and life satisfaction in persons with spinal cord injury. Archives of Physical Medicine and Rehabilitation 2012;93:82-89.

31. Livneh H, Martz E. Coping strategies and resources as predic- 
tors of psychosocial adaptation among people with spinal cord injury. Rehabilitation Psychology 2014;59:329-339.

32. Bush EG, Rye MS, Brant CR, Emery E, Pargament KI, Riessinger CA. Religious coping with chronic pain. Applied psychophysiology and biofeedback 1999;24:249-260.

33. Turner JA, Jensen MP, Romano JM. Do beliefs, coping, and catastrophizing independently predict functioning in patients with chronic pain? Pain, 2000;85:115-125.

34. Sharpe L, Sensky T, Allard S. The course of depression in recent onset rheumatoid arthritis: the predictive role of disability, illness perceptions, pain and coping. Journal of Psychosomatic Research 2001;51:713-719.

35. Grotle M, Foster NE, Dunn KM, Croft P. Are prognostic indicators for poor outcome different for acute and chronic low back pain consulters in primary care? Pain, 2010;151:790-797.

36. Benka J, Nagyova I, Rosenberger J, Macejova Z, Lazurova I, van der Klink et al. Social participation in early and established rheumatoid arthritis patients. Disability and Rehabilitation 2015;38:1172-1179.

37. Nagyova I, Stewart RE, Macejova Z, van Dijk JP, van den Heuvel WJ. The impact of pain on psychological well being in rheumatoid arthritis: the mediating effects of self esteem and adjustment to disease. Patient Education and Counseling 2005;58:55-62.

38. Badura Brzoza K, Zajac P, Brzoza Z, Kasperska Zajac A, Matysiakiewicz J, Piegza. et al. Psychological and psychiatric factors related to health related quality of life after total hip replacement-preliminary report. European Psychiatry 2010;24:119-124.

39. Ristner G, Andersson R, Johansson LM, Johansson SE, Ponzer $\mathrm{S}$. Sense of coherence and lack of control in relation to outcome after orthopaedic injuries. Injury, 2000;31:751-756.

40. Wright MA, Wren AA, Somers TJ, Goetz MC, Fras AM, Huh BK. et al. Pain acceptance, hope, and optimism: relationships to pain and adjustment in patients with chronic musculoskeletal pain. The Journal of Pain, 2011;12:1155-1162.

41. deRoon Cassini TA, de St Aubin E, Valvano A, Hastings J, Horn P. Psychological well being after spinal cord injury: Perception of loss and meaning making. Rehabilitation Psychology, 2009;54:306-314

42. Ramírez Maestre C, Esteve R. The role of sex/gender in the experience of pain: resilience, fear, and acceptance as central variables in the adjustment of men and women with chronic pain. The Journal of Pain 2014;15:608-618.

43. Silverman AM, Molton IR, Alschuler KN, Ehde DM, Jensen
MP. Resilience predicts functional outcomes in people aging with disability: a longitudinal investigation. Archives of Physical Medicine and Rehabilitation 2015;96:1262-1268.

44. Coffey L, Gallagher P, Desmond D. Goal pursuit and goal adjustment as predictors of disability and quality of life among individuals with a lower limb amputation: a prospective study. Archives of Physical Medicine and Rehabilitation 2014;95:244-252.

45. Lyrakos DG. The impact of stress, social support, self efficacy and coping on university students, a multicultural European study. Psychology, 2015;3:143-149.

\section{THE IMPORTANCE OF PSYCHOLOGICAL RESOURCES TO ADJUSTMENT TO DISABILITY AMONG MOBILITY IMPAIRED INDIVIDUALS}

\section{Alčiauskaitė, L. Šinkariova}

Key words: psychological resources, adjustment to disability, mobility impairment.

Summary

In the past years there has been a growing interest in psychological resouces of mobility impaired individuals. Such research is often focused on a one single resource. but because of the unaccounted variance, there are perhaps a range of other psychological resources that could be contributing. A summary of current findings on psychological resources could provide a basis for better understanding of adjustment and could be used to develop and apply interventions tailored to strengthen people with mobility impairment.

The purpose of this study was to gain a systematic overview of the role of psychological resources in the adjustment to disability among mobility impaired individuals.

A total of 45 studies which met the inclusion criteria were identified. General self efficacy, perceived social support, coping strategies and self esteem are the most analysed psychological resources. All of them except self esteem, are related to all aspects of adjustment to disability.

Research on psychological resources in adjustment to mobility disability is broad, but also fragmented. Associations of psychological resources with physical and mental health and well being were frequently shown, while associations with psychosocial aspects of adjustment to disability are rarely studied. Further development of such studies is indicated.

Correspondence to: laura.alciauskaite@gmail.com

Gauta 2017-10-31 